\title{
Chemistry Licentiate Degree Through the De MODALITY FROM THE IFMT: PERCEPTIONS OF TRAINER TEACHERS
}

\author{
LICENCIATURA EM QUÍMICA NA MODALIDADE EAD DO IFMT: \\ PERCEPÇÕES DOS PROFESSORES FORMADORES
}

DOI: 10.23926/RPD.2526-2149.2020.v5.n2.p982-998.id676

\author{
Marcelo Franco Leão \\ Doctor in Sciences \\ Education from UFRGS. \\ Professor at the IFMT \\ Confresa Campus. \\ marcelo.leao@cfs.ifmt.edu.b \\ $\underline{\mathrm{r}}$

\section{Eniz Conceição \\ Oliveira} \\ Doctor in Chemistry from \\ UFRGS. \\ Professor at UNIVATES. \\ eniz@univates.br
}

\section{José Claudio Del Pino \\ Doctor in Biomass from \\ UFRGS}

Professor at UFRGS.

delpinojc@yahoo.com.br

\begin{abstract}
This study aimed to identify significant aspects during the trainer teachers' early training, as well as existing challenges and gaps during the Distance Education Degree and the characteristics of the teachers' praxis during the training process. The research took place in the first semester of 2018 and involved 17 trainers from the IFMT Chemistry Licentiate Degree Course. An electronic data form, comprising 7 questions was used to collect the data that was interpreted through content analysis. The theories studied, the practical activities and the pedagogical approach were relevant to the training received. The gaps identified in the IFMT Licentiate Degree course were: lack of practical activities, precarious student training, and system limitations. Regarding the teachers' praxis, the importance of class planning and the contributions provided were highlighted. From those perceptions, it was understood how the training process occurs at the IFMT, which will allow for planning actions to promote improvements to the course.
\end{abstract}

Keywords: Distance Education. Teacher Training. Chemistry Licentiate Degree. Teacher Praxis.

Resumo: O presente estudo teve por objetivo identificar aspectos significativos na formação inicial dos professores formadores, desafios e lacunas existentes no curso de licenciatura em EaD e características da atuação docente neste processo formativo. A investigação ocorreu no $1^{\circ}$ semestre de 2018 e envolveu 17 formadores do Curso de Licenciatura em Química do IFMT. Foi utilizado um formulário eletrônico para coletar dados, constituído por 7 questões abertas, cujas respostas foram interpretadas por análise de conteúdo. As teorias estudadas, atividades práticas realizadas e postura pedagógica foram marcantes na formação que receberam. Algumas lacunas puderam ser identificadas no curso de licenciatura do IFMT: carência de atividades práticas, formação precária dos estudantes, limitações quanto ao sistema. Sobre a atuação docente, ressaltaram a importância do planejamento e as contribuições proporcionadas pelas aulas. Com estas percepções compreendeu-se como está ocorrendo o processo formativo no IFMT, o que possibilitará planejamento de ações que promovam melhorias no curso.

Palavras-chave: Educação a distância; Formação de professores; Licenciatura em Química; Prática docente. 


\section{INTRODUÇÃO}

During the last decades, due to the constantly changing society through scientific and technological advancements, teacher training has faced the challenge of providing quality teaching that includes the use of computers (VASCONCELOS; VIEIRA; DANTAS, 2015). Within this new educational context of Distance Education (DE), trainer teachers play a fundamental role for the education process to fulfill its purpose.

Studies carried out by Massena and Monteiro (2011) show that research on training and trainer teacher practices are intensifying. The authors advocate that trainer teachers, as well as students, are the fundamental players in this training process, which justify the importance of researching them.

One other aspect to consider is that perhaps university professors were not prepared to be trainer teachers, since most licentiate degree courses, not so long ago, privileged scientific knowledge over pedagogical knowledge (MASSENA; MONTEIRO, 2011). They believe that, ideally, trainers should have discussed about the training of teachers during their early training, the conceptual re-elaboration, the didactic transposition and the teacher praxis.

Vasconcelos, Vieira \& Dantas (2015) point out that it is during early training that knowledge is built and the skills are developed to perform teaching, which is increasingly more diversified to meet the demands of contemporaneity. Those studies show that early teacher training has focused increasingly further on scientific concepts, which are not unnecessary, but very often, not all of them end up being employed in education practice in the classroom.

Tardif (2012) advocates that the more in-depth knowledge in early training should be able to open spaces for reflection. In other words, the author indicates that in licentiate degree courses it is common for trainers to prioritize the familiarization of the scholars with what is to be their professional occupation and their area of action, thus stimulating the practice of reflection.

If certain concepts, skills and techniques are not developed during early training, when entering a Basic Education classroom, they may be lacking arguments when faced with some unexpected questioning that students may formulate, since these pieces of knowledge are different to those constructed along the training trajectory. Hence, Vieira \& Dantas (2015) alert for there to be wholesome training aimed at Basic Education, that is, the training process must be founded on the development of research, on critical reflection of the individuals under training, and on the construction of freedom to take a stand and act when faced with problems that may arise. 
Considering the above, the purpose of this study is to identify the aspects that impacted the trainer teachers' early training, as well as the challenges met and gaps identified in the Chemistry Licentiate Degree at the Mato Grosso Federal Institute for Education, Science and Technology (IFMT), in addition to the characteristics of teacher praxis in this DE training process.

\section{THEORETICAL DISCUSSIONS ON TEACHER TRAINING}

When considering the new educational setting, permeated by technologies and information, more than the posture and words spoken in the classroom, planning has become more decisive, along with the timing and presentation of the activities and materials the trainer teacher sets up in the virtual environment, which in DE is the education space par excellence. That is, it is by means of the trainers' pedagogical activities that possibilities are created for students to construct the necessary and required knowledge for the profession. This reinforces Freire's (1995, p. 47) position in stating: "Teaching is not transferring knowledge, but creating possibilities for its own production or its construction".

It is worth highlighting that it is the teacher who creates and intermediates the knowledge construction possibilities. Teaching in a way that is not linked to the social context the students are inserted makes no sense to them, because

[...] the ideal teacher is someone who must know their subject matter, their discipline and their program, in addition to having knowledge related to education and pedagogy sciences and develop practical knowledge based on their daily experience with students (TARDIF, 2012, p. 39).

From the same strand, Nóvoa (1995) indicates the need to think out early training from a starting point of in-depth reflection about the teaching profession. According to the author, such training must consider and contribute towards the three forms of development: personal, or related to the teacher's life; professional, or related to the teacher praxis; and organizational, or related to the knowledge produced in school.

According to data presented by Mesquita \& Mota (2014), the offering of licentiate degree courses, mainly in the sciences area, is one of the purposes the Federal Institutes (FIs) took on since their transformation. It is worth highlighting that some FIs originated from the previous Federal Technological Education Centers (CEFETs), where intermediate level technical teaching was predominant, but as from 2009 they underwent a broad expansion and took on Higher Education as well. 
The above mentioned authors warn that the trainer teacher staff in those institutions is the same that works in Basic Education technical and technological teaching aimed at specific technical-industrial and/or farming professionals. This way, it is supposed that early teacher training at the IFs does not include all training aspects that are specific for teacher training.

Still according to Mesquita \& Mota (2014), it is not clear what the potentials and difficulties those professional education institutions have to provide teacher training. They advocate the need to promote reflections that contribute towards re-structuring the chemistry licentiate degree courses by considering the current training needs that require a critical, emancipating reflection upon the pedagogical practices developed during Basic Education.

One other challenge the chemistry licentiate degree courses face is the persisting dichotomy between theory and practice. According to Maldaner (2006), those early teacher training courses are criticized for the fact that they are not efficient in the sense of qualifying the future professionals with a broad view of what shall be the professional praxis of the chemistry teacher.

Being a chemistry course, the trainers should consider the contributions experimentation provides towards comprehending chemical concepts. For Fernandes \& Silva (2004), the construction of scientific knowledge can take effect within experimental contexts that allow students to re-structure and construct their knowledge and skills.

Moreover, the official educational documents themselves that regulate the operation of chemistry licentiate degree courses "recommend the use of experimentation, emphasizing the theory-experiment relation by incorporating interdisciplinarity and contextualization" (SILVA; MACHADO; TUNES, 2010, p. 244). In this sense, it becomes evident that experimentation provides countless benefits in the early training of chemistry teachers, since it will qualify them to employ it in various ways in their future pedagogical practices.

In addition to the fundamental knowledge of the profession, increased commitment is necessary from the DE teacher training course trainers. According to Litto \& Formiga (2009, p. 107), to work in this teaching modality requires the articulation of methodologies and strategies that provide students with "the development of creativity, autonomy and freedom to self-manage learning, the pursuit and selection of different contexts within which they are interested in interacting, sharing experiences and co-manage the training”.

To be a trainer teacher requires attention and specific skills in order to make the training process objective and involving. To work on-line, according to Silva \& Cilento (2014), teachers must reinvent their pedagogical practices that were traditionally constructed within a different 
context, usually inside four walls. That is, teachers who work in the DE modality will naturally carry with them knowledge and postures that were constituted during their attendance practice that will influence their actions in on-line training.

In this sense, to work in on-line training requires considering the elements involved in the education process, that is, it is not only the programs, frameworks or concepts that determine good development in DE licentiate degrees, but education that is aimed at motivating students (SILVA, 2012). The training advocated by the author is one that is able to provide learning that will be useful for future professional activity, since the trainers are also teachers and their experiences contribute towards and reflects on those who contributed during training.

On this subject, Berge (1996) points out four fundamental functions/competences for the DE trainer teacher, namely, pedagogical, social, managerial and technical support. With this understanding, the trainer teachers need to develop their pedagogical practices in such a way as to articulate those four competences among themselves.

According to Vasconcelos, Vieira \& Dantas (2015), the training process is intermediated and facilitated for DE students by means of an involving methodology that questions and allows to research information to respond to that questioning. Thus, management is necessary to create a learning environment that favors communication and interactions with the colleagues. In the authors' views, DE teaching performs pedagogical, managerial, social and technical support functions.

The above mentioned authors believe that those functions set in motion teaching knowledge that allows the trainers to act effectively in learning situations that occur during the course. Thus, it is expected that early training provide a favorable environment and result in positive reflections on the future professional praxis.

\section{Methodological Procedures}

This research is of a descriptive, exploratory nature from a qualitative approach. According to Moreira \& Calefe (2008), research from a qualitative approach is that which explores the subjective characteristics of the process in which the individuals are involved that are not possible to describe numerically. This type of approach is indicated for studies involving the educational field as it allows to interpret the results in accordance with the conduct line of the investigated by providing information from the private to the general.

The study object chosen for investigation is the Chemistry Licentiate Degree Course offered through the DE modality by the IFMT Cuiabá - Bela Vista Campus. It was developed 
during the first semester of 2018. This investigation comprises a portion of a doctorate research aimed at identifying teacher knowledge constructed during this course, and presented at the Stricto Sensu Post-Graduation Program in Sciences Education: Chemistry of Life and Health (PPGQVS) promoted by the Rio Grande do Sul Federal University (UFRGS).

This survey was delimited by the perceptions of the trainer teachers, with others involved in this training process having also been researched, but those studies constitute other texts. It needs to be informed that before carrying out the study, the project was presented to and discussed with those responsible for the course (UAB/IFMT coordinator, IFMT Cuiabá Bela Vista campus dean and coordinator of the respective course), who authorized it to be carried out and signed a letter of agreement.

The course coordination permitted the researcher to attend the course pedagogical planning meetings (that took place in the first week of February 2018) to present the general information about the purpose of the study, the proposed procedures, the confidentiality assurance, and other necessary clarifications.

At the occasion, the trainer teachers were invited to voluntarily take part in the research. Those who agreed signed the Term of Consent (ToC)

The following criteria were observed to select which trainer teachers were to be investigated: be working or have worked in the course; accept taking part in the research and have elaborated at least one teaching plan, that is, having taken on the condition of being responsible for at least one discipline.

The data collection instrument used, as requested by the trainer teachers, was an electronic form (Google Forms) containing seven open questions. It needs to be clarified that the first one served to characterize the participating public that totaled 17 (seventeen) trainer teachers and whose names were replaced with alphanumeric characters from TT1 to TT17.

Chart 1 presents characteristics about the early training of the investigated.

Chart 1 - Characteristics of early training of the trainer teachers

\begin{tabular}{l|l|}
\hline \multicolumn{1}{|c|}{ Graduations } & Quantity \\
\hline Chemistry Licentiate Degree & $10^{*}$ \\
\hline Pedagogy Licentiate Degree & 1 \\
\hline Letters Licentiate Degree & $2 * *$ \\
\hline Biological Sciences Licentiate and Bachelor Degrees & 1 \\
\hline Chemistry Bachelor Degree & 2 \\
\hline Food Engineering & 1 \\
*Two of them hold other licentiate degrees, one in Physics the other in Pedagogy. \\
$* *$ One with qualification in Portuguese/English the other in Literature
\end{tabular}

Source: Elaborated by the authors (2018). 
Regarding the time since finishing early training, four of them did so in the 1980s in the last century, with 1980 being the graduation of the oldest trainer teacher, with a licentiate degree in chemistry. Five of the investigated graduated in the 1990s, and the other seven graduated between 2000 and 2007. This goes to show that the trainer teacher staff in this course is very experienced, with all of them being graduated for over ten years.

The Mato Grosso Federal University (UFMT) was the Higher Education Institution (IES) responsible for the academic training of most teachers above, with a total of ten of them, and was also responsible for the second licentiate degree of one of the teachers. Three other teachers graduated from the Mato Grosso State University (UNEMAT). Two of the investigated teachers received their early training in Southeastern Brazil, one from the Rio de Janeiro Federal Rural University (UFRRJ) and the other from the Rio de Janeiro Federal University (UFRJ). Two other teachers graduated from IES in Rio Grande do Sul, one from the Santa Cruz do Sul University (UNISC), the other from the Passo Fundo University (UPF).

It should be pointed out that all received their early training in class attendance, that is, their work in the course is their first experience with teacher training in the DE modality. It is highlighted that most trainers received training at the Stricto Sensu level, which is recommended for Higher Education courses.

The methodology employed to analyze the results from the other six questions was the set of techniques known as content analysis. According to Bardin (2012), this method makes it possible to extract from the answers provided by the participants the message that refers to the subject being investigated. The categorization technique occurred by means of grouping up similar answers in an emerging and frequent fashion. That categorization involved criteria to interpret and classify the data collected, which could occur in a different manner if carried out by a different researcher.

\section{Results ANd Discussions}

Three categories emerged from the answers provided by the participants: significant aspects in the training of the trainer teachers; challenges met in DE and gaps identified in the course; and pedagogical practice adopted by the trainers when teaching the lessons in the course. Within each category, sub-categories emerged, as schematized in Chart 2. 
Chart 2 - Schematics of the results organization

\begin{tabular}{|c|c|c|}
\hline Categories & Sub-categories & Sources/Questions \\
\hline \multirow{4}{*}{$\begin{array}{l}\text { Significant aspects in } \\
\text { the training of trainer } \\
\text { teachers }\end{array}$} & Theories studied & \multirow{4}{*}{$\begin{array}{l}\text { 2) How was your relation with your trainer } \\
\text { teachers, which strategies did they employ and } \\
\text { which positive practice aspects impacted your } \\
\text { training? } \\
\text { 3) During your early training, which were the } \\
\text { main references studied (pedagogical and } \\
\text { specific), what learning was constructed and } \\
\text { teaching knowledge developed along that } \\
\text { trajectory? }\end{array}$} \\
\hline & Practical activities performed & \\
\hline & Posture adopted by the teachers & \\
\hline & & \\
\hline \multirow{3}{*}{$\begin{array}{l}\text { Challenges found in DE } \\
\text { and gaps identified in } \\
\text { the course }\end{array}$} & Lack of practical activities & \multirow{3}{*}{$\begin{array}{l}\text { 4) As to your professional activity in the course, } \\
\text { did you face any difficulties and challenges to } \\
\text { work as a DE trainer? } \\
\text { 7) What gaps and challenges do you perceive in } \\
\text { the course training process? }\end{array}$} \\
\hline & $\begin{array}{l}\text { Weak student preparation in } \\
\text { Intermediate Education }\end{array}$ & \\
\hline & $\begin{array}{c}\text { Limitations regarding the DE } \\
\text { system }\end{array}$ & \\
\hline \multirow{2}{*}{$\begin{array}{l}\text { Pedagogical practice } \\
\text { adopted by the trainers } \\
\text { when teaching classes } \\
\text { in the course }\end{array}$} & Importance of teacher planning & \multirow[b]{2}{*}{$\begin{array}{l}\text { 5) How do you plan your classes, which } \\
\text { strategies, methodologies, resources and } \\
\text { materials do you employ in attendance classes } \\
\text { and in the virtual classroom? } \\
\text { 6) What learning is made possible for students } \\
\text { in your classes? }\end{array}$} \\
\hline & $\begin{array}{l}\text { Contributions provided by the } \\
\text { classes }\end{array}$ & \\
\hline
\end{tabular}

Source: Elaborated by the authors (2018).

As can be perceived, the first category refers to the impacting aspects in the early training they received. The data from the second and third questions in the form allowed for the identification of the following sub-categories: theories studied; practical activities performed; and posture adopted by the teachers.

As to the theories studied during their early training and that in some way influenced in the construction of the professional profile, nine trainer teachers recalled references to the specific areas of knowledge. Some answers illustrate such statement, such as: "I remember we studied Ricardo Feltre, Chassot, Atkins, Vogel`s, Paulo Freire...so many, it surely is hard to quote" (TT2). "I can't specify the references, but they were not few, mainly in the specific area" (TT6). "The learning theory I most identified with was David Ausubel's the Theory of Meaningful Learning" (TT7). "The pedagogy course studies basically the whole time those authors who lay the foundations of pedagogical practices, such as didactics, curriculum, planning and evaluation" (TT8). "Several references were studied about: methodologies for teaching Chemistry; instrumentation for teaching Chemistry; scientific alphabetization, early and continued training, theory of Learning, Pedagogy of freedom, Evaluating learning" (TT9).

"The specific references were mostly employed, mainly those specific on organics, for example it was Solomons, Generally it was Kossel” (TT10). "José Carlos Libâneo, Cipriano Luckesi, Paulo Freire, Moacir Gadotti” (TT13). “There were few pedagogical references we studied. I only recall: Paulo Freire, Jean Piaget and Vygotsky. In the specific chemistry area it 
was the classic references: Atkins, Bacaan and Russell" (TT14). "I recall two from the pedagogical area "Genetic epistemology" (Jean Piaget) and "Pedagogy of freedom" (Paulo Freire). The specifics are several references" (TT17).

As can be found in most answers, there were many authors from the area mentioned by the participants and few authors from the pedagogical area, except for those who graduated from specific courses aimed at Pedagogy. Four teachers mentioned Paulo Freire and two of them quoted Jean Piaget as references studied during early training, as well as other authors who were remembered one single time, for example, Vygotsky

Such finding is of concern, since they are teacher trainers and the pedagogical foundation is indispensable for everyone who works in licentiate degree courses, regardless of the area of knowledge, since the practice itself of the trainer teachers constitutes valuable teaching (NÓVOA, 1995). Authors Massena \& Monteiro (2011) also warn about gaps on a pedagogical nature in early trainer teacher training, and that overcoming such training shortcomings may or may not occur throughout the teacher praxis, this being a convenient moment to take on a reflective attitude towards their own practice.

Tardif (2012) states that teacher knowledge is plural and necessary for teachers to work in the contemporaneity. In this sense, during early training it is necessary that future teachers learn about the scientific concepts they will be teaching, the teaching methodologies they may employ and a general perception of the discipline for which they will be responsible. However, the author suggests that, in order to teach such concepts, it is necessary to also consider the experiences lived during the early training and even while exercising the profession.

One other aspect deemed impacting during the training they received are the experimental practical activities performed. Below are some expressions that illustrate such statement: "The experimental part of my course was very intense, I believe those were the chemistry experimental practices that impacted my training" (TT1). "I had teachers who liked practical classes, which I could say impacted me. As a teacher who really likes practical classes, I believe that is what I learned mostly" (TT2). "There were very good laboratory classes, as well as the development of practices with alternative materials that influenced my practices today" (TT7).

"What I deem impacting is the methodology adopted in theoretical and practical classes, with a few technical visits because they were well founded" (TT14). "I had some practical classes and they impacted me the most" (TT16). "Being an experimental area, the laboratory 
practice and technical visit routines weighed heavily in sedimenting the contents being studied" (TT17).

There is no discussion that experimentation is a good pedagogical tool to help understand chemical concepts, as it provides reflections and research when explored in an effective fashion (FERREIRA; HARTWIG; OLIVEIRA, 2010). The importance experimental activities have for chemistry students is confirmed by Silva, Machado \& Tunes (2010), who advocate the benefits provided by experiments in the training process, among which being the possibility of providing research, be a means to promote interdisciplinarity, involving teaching strategy, provide the exchange between theory and practice, as well as favoring the establishment of relations between the chemical concepts being studied and daily life.

However, Ferreira, Hartwig \& Oliveira (2010) warn about the care needed in the development of experimental activities to avoid doing practice for practice's sake, that is, the authors advocate an investigative experimentation to avoid 'cake recipes', that is, the development of practices of a positive nature that is highly recurrent in chemistry courses.

One other impacting aspect in early training they had was the posture adopted by the teachers in their courses. The posture that their trainers assumed had both positive and negative impacts and certainly carries reflections in the practices adopted or avoided by the investigated teachers. Some of the aspects are:

"Most of my teachers were very traditional and bookish, but some were more daring and innovative, attempting to contribute and make the difference" (TT3). "Throughout my early and continued training I attended many activities, discussions, debates, group work, presentation, seminars and research, that impacted me" (TT6). "I received training from highly qualified teachers who, despite being traditional, added a lot to my training" (TT8) "The methodologies employed during my graduation were mostly expository lectures and traditional ones, however, the teachers were committed and responsible" (TT9).

"The teachers who impacted my training employed the methodology of group work with seminars, debates, round tables, theater and research projects, where scholars would have the opportunity to exhibit their work" (TT11). "What impacted the most was the skill some teachers had to involve the students during their classes. The most challenging disciplines were the most interesting to me and the ones that had a greater impact" (TT15).

It can be observed from the statements by TT3, TT8 and TT9 on the impacting facts in their early training that the traditional teaching methodology is predominant. It should be highlighted that most participants in this study finished their graduation courses more than 20 
years ago and this teacher centered learning conception was predominant in their courses. Teacher training occurred from a traditional teaching strand that prioritizes the transfer of knowledge, does not consider the thinking of Freire (1996) that the teaching practices adopted by teachers need to create possibilities for the production or construction of knowledge to take place.

On the other hand, from the answers by TT6, TT11 and TT15 it can be perceived that the training they received considered important aspects for practicing teaching, mainly related to the diversification of teaching strategies. This finding reinforces the thinking of Nóvoa (1995) that early teacher training needs a clear and objective collective project capable of mobilizing the group of students, which contributes towards socially ascertaining the future teachers being autonomous and committed to human training, having lived through such experiences.

The second analysis category covers the challenges faced in DE and gaps identified in the course. From the answers to the fourth and seventh questions in the form, the following subcategories emerged: lack of practical activities; weak student preparation in Intermediate Education; limitations regarding the DE system.

The lack of experimental activities during the course was a gap identified by the majority of participating trainers. Below are some answers that illustrate such statement: "The specific disciplines lack practical lessons, technical visits, project development; these are limiting factors and the gaps that I perceived in the licentiate training in the DE modality" (TT3). "Some gaps that are present in the course are the lack of a physical/laboratory structure and personnel at the hubs" (TT5). "I still feel the need of greater proximity to and better utilization of the laboratories" (TT6). "In relation to specific and scientific knowledge, the lack of a structure for practical laboratory classes, which should greatly compromise training of teachers in an area that, in its essence, the practice of handling equipment and materials is indispensable" (TT17).

From the quoted statements above, it can be observed that students in this course are lacking the educational potential provided by experimentation, which was so important and present in the early training of their trainers. By not performing or having a reduced amount of experimental activities, favorable conditions for reflection and research are not being created to establish a relation between theory and practice, in addition to the interdisciplinary and contextualized character highly advocated by Maldaner (2006), Fernandes \& Silva (2004), Ferreira, Hartwig \& Oliveira (2010) and by Silva, Machado \& Tunes (2010). 
Below are three other selected answers that reaffirm the experimentation gap, but also point out suggestions to solve such a problem: "There are some difficulties as to the practical part of the discipline, but as to the learning of pedagogical knowledge it is satisfactory. It is necessary to seek alternative strategies to favor learning in the practical part of the area" (TT11).

"The lack of an experimental laboratory can be met with alternative materials, since our future teachers will be facing this same reality in the schools in which they probably will be inserted" (TT13). "Perhaps the course does not prepare very well for experimental practical activities, being a distance course. One alternative for the course, which is never to be considered a replacement for a laboratory, would be the use of software (virtual laboratories) that simulate the laboratory" (TT15).

It can be noticed that the suggestions offered originate from their knowledge constructed with the DE experience, that is, they found a solution in diversifying teaching strategies, using alternative materials and exploring virtual laboratories for the situation the live when teaching classes in this modality. Such knowledge of the practice is only constructed by living through learning situations, which Tardif (2012) calls knowledge from experience.

One other lack identified in the course relates to weak student preparation. Some of their answers were: "I see many gaps regarding learning in students presenting basic difficulties in reading, mathematics and chemistry from Intermediate Education. We also have students who already have a degree and do not take the course very seriously" (TT1). "Although DE students may organize their own study schedules, there are many unforeseen events especially with regards to platform availability and misinformation between coordinator-hub-tutors-students" (TT6). "DE students must be highly organized to be able to follow the course, which does not always happen. It takes will power and commitment to develop all the necessary skills to be a good professional" (TT9). "One of the most difficult points is dealing with students' level of instruction, where some already have higher education training and others who can barely read or express themselves in writing" (TT17).

This problem that was identified by a large portion of trainer teachers confirms the results obtained by Caetano \& Rezende Junior (2009) that a significant number of students in this teaching modality present previous training gaps, and that, according to the authors, has a negative influence on their study performance and proposed activities, even oftentimes, leading them to abandon the course.

In the face of this issue, Litto \& Formiga (2009) advocate that trainer teachers who work in DE courses be decisive to overcome student difficulties as well as towards their success in 
the training process. That is, it is necessary to intervene in such situations, create involving learning situations and articulate the necessary strategies for students' intellectual development and thus overcome the shortcomings found.

One third challenge identified by the participating trainers refers to structure and organization limitations in the DE course. Below are presented some answers: "One difficulty was the lack of training and a more solid preparation to work in DE. I know we could explore better the available tools" (TT4). "The Internet is precarious at the hubs, hindering the meeting of paper deadlines. One other problem is about the students that get enrolled during the course, that is, the discipline is ending and even so students get enrolled" (TT12). "Lack of pedagogical support, seminars/congresses related to the course. Suggestion: Qualification courses" (PF14). "I fear that, due to the lack and/or low frequency of attendance meetings, these students may not develop the skills to relate with and deal with human beings in an educational environment" (TT17).

Limitations are imposed by the own environment where DE courses take place. However, Silva (2012) states that teachers in this teaching modality need to go beyond the structural elements such as system, course organization, the virtual environment, the chemical programs and concepts. The author believes that DE training must create opportunities for situation in which multiple learning occurs.

The third category refers to the pedagogical practice adopted by these trainers when teaching classes in the course. From the answers provided for the fifth and sixth questions in the form the following sub-categories emerged: the importance of teacher planning and the contributions provided by the classes.

About the importance of teacher planning, some answers were selected to bring such finding to evidence: "My classes contain participative learning and query forums. on-line activities, web-conference and updated articles, since the discipline has no workbook. I plan for the semester, and, when students enter the classroom, they have available the study guide and teaching plan" (TT2). "I organize content approach following the didactic material. I prepare forums that lead to discussion of themes that are related to the content to be worked on and at the same time becomes a debate center through the medium" (TT4). "The virtual classes are planned to provide support to the academic, I post didactic materials about the theme, models of report class plans and all the sequences for my planning" (TT5).

"I plan based on the discipline study program. I use updated videos and texts on the subject, but the basis is the discipline material. I use a weekly doubts forum and on-line 
activities" (TT8). "The classes are planned in advance and during the periods are subject to upgrades. Doubts forum and chat rooms are used. The materials used are: workbook, video classes, virtual books and experiments whenever possible" (TT13). "I plan the classes in advance. I have to find ways of following the pupils' learning, which is not so easy in a DE course. I use texts and workbooks as resources, but am aware there are others to be explored" (TT16).

It can be observed that these trainer teachers are concerned with teaching plans, organization, strategies, resources they employ and learning assessment, all of that for the course to meet its objectives and train qualified professionals. The attributions listed by the trainer teachers are essential for the training process, regardless of whether the course is DE. According to Vasconcelos, Vieira \& Dantas (2015), trainers are responsible of providing pedagogical, social, managerial assistance, as well as technical support for students.

As to the contributions provided by the classes they teach in the course, some answers were selected: "I try to show my students some practices, methodologies and strategies to work in basic education, I focus strongly on critical training, as well as the necessary ideological commitment to educate" (TT3). "I expect them to learn the foundations and specific concepts of the knowledge area, I try to stimulate their critical sense" (TT4). "We are preoccupied with developing feasible methodologies and practical activities for students to bring to the classroom and teach different classes from the traditional ones" (TT6). "Students are instigated in my classes. Learning this way is constructed according each one's life reality, of their subsumers" (TT7).

"In my practices I pursue a human training intending to make comprehension of the knowledge possible to the students" (TT9). "For chemistry scholars I believe it is also necessary to have the pedagogical competences and knowledge to work with deaf students in inclusive classes" (TT11). "I try to follow a questioning pedagogy, that is, the learning process mediated by questions that allow to investigate a problem aimed at developing the inquisitive, critical and creative thinking" (TT14). "I expect my classes to make it possible for students to develop reasoning, autonomy and responsibility for their learning" (TT17).

As was indicated by Silva \& Cilento (2014), it can be perceived that these trainer teachers need to reinvent their pedagogical practices, because the experiences they had during their early training occurred in a different context, all in the attendance modality. The authors advocate such reinvention for the negative reflexes not to be reproduced in the pedagogical practices adopted in this on-line training. 
It is perceived in some answers there is a concern with the development of important teacher skills in present times, such as those advocated by Litto \& Formiga (2009), namely creativity, autonomy and freedom to self-manage learning. Such yearning matches the thinking by Massena \& Monteiro (2011) who highlight the need for a change in the training process predominant focus. For the authors, it is necessary to overcome the conception that teaching occurs through transmission and is centered in the teacher figure to then promote teaching that incites, questions and creates opportunities to construct knowledge, with the teacher being responsible for providing such situation and learning.

\section{Final Considerations}

Upon investigating trainer teachers from a chemistry licentiate degree course offered in the DE modality it was possible to identify major aspects involving the early training they received. From the results attained, it is possible to affirm that specific knowledge of chemistry was impacting in the academic trajectory of the investigated. On the other hand, there was a weak discussion about pedagogical knowledge. One other impacting aspect refers to the constant performance of experimental practices in their degrees, in addition to the posture adopted by their teachers, both examples to follow and practices to be avoided.

As to the challenges met while working as trainers in a DE course and the gaps identified throughout the work action, it was mentioned that experimental activities are seldom performed in the course. They also mentioned that many students received weak training from Intermediate Education without qualified professionals may harm the development of studies, besides the limitations imposed by the own system or course structure.

Regarding the pedagogical practice taken on when teaching their classes, the trainers pointed out the importance of previous planning and organizing the activities proposed, as well as identifying some contributions provided or expected by means of the classes they teach. Therefore, it is expected that the identification of the influences in the training route while they were students, the perceptions on the course and the pedagogical actions developed as trainer teachers serve as an evaluation indication for the IFMT Chemistry Licentiate Degree course in DE.

\section{REFERENCES}

BARDIN, Laurence. Análise de conteúdo. São Paulo: Edições 70, 2012. 
BERGE, Zane Laurent. Example case studies in post-secondary, on-line teaching. In: G. Hart \& J. Mason. Proceedings of the 'Virtual University? Symposium'. Melbourne, Australia, n. 21, n. 22, p. 99-105, November, 1996.

CAETANO, Thiago Costa; REZENDE JUNIOR, Mikael Frank. A visão dos tutores no curso de licenciatura em física, modalidade a distância, da Universidade Federal de Itajubá - MG. In: XVIII Simpósio Nacional de Ensino de Física, 2009, Vitória-ES. Atas... São Paulo: Editora da SBF, 2009.

Disponível em:

http://www.cienciamao.usp.br/tudo/exibir.php?midia=snef\&cod=_avisaodostutoresnocursod. Acesso em: 07 ago. 2018.

FERNANDES, Maria Manuela; SILVA, Maria Helena Santos. O trabalho experimental de investigação: das expectativas dos estudantes as potencialidades no desenvolvimento de competências. Revista Brasileira de Pesquisa em Educação em Ciências, v. 4, n. 1, p. 4558, jan/abr., 2004. Disponível em: https://periodicos.ufmg.br/index.php/rbpec/article/view/4095. Acesso em: 13 jun. 2018.

FERREIRA, Luiz Henrique; HARTWIG, Dácio Rodney; OLIVEIRA, Ricardo Castro de. Ensino experimental de química: uma abordagem investigativa contextualizada. Revista Química Nova na Escola, v. 32, n. 2, p. 101-106, 2010. Disponível em: http://qnesc.sbq.org.br/online/qnesc32_2/08-PE-5207.pdf. Acesso em: 07 ago. 2018.

FREIRE, Paulo. Pedagogia da Autonomia: Saberes necessários à prática educativa. São Paulo: Paz e Terra, 1996.

LITTO, Fredric. Michael; FORMIGA, Marcos. (org.) Educação a distância: o estado da arte. 1. ed. São Paulo: Pearson Education do Brasil, 2009.

MALDANER, Otavio Aloisio. A formação inicial e continuada de professores de química: Professores/Pesquisadores. 3. ed. Ijuí: Unijuí, 2006.

MASSENA, Elisa Prestes; MONTEIRO, Ana Maria Ferreira da Costa. Concepções sobre currículo de formadores de professores: o curso de licenciatura em Química do Instituto de Química da Universidade Federal do Rio de Janeiro. Química Nova (Impresso), v. 34, p. 1476-1484, 2011.

MESQUITA, Nyuara Araújo da Silva; MOTA, Rejane Dias Pereira. A pesquisa nas licenciaturas em química dosinstitutos federais de Goiás: identidades em trânsito. Revista Tecné, Episteme y Didaxis: TED, v. extraordinário, p. 1006-1012, 2014.

MOREIRA, Herivelto; CALEFE, Luiz Gonzaga. Metodologia da pesquisa para professor pesquisador. 2. ed. Rio de Janeiro: DP\&A, 2008.

NÓVOA, António. Formação de professores e profissão docente. In: NÓVOA, A. (Coord.) Os professores e sua formação. Lisboa: Publicações Dom Quixote, 1995.

SILVA, Marco. (org). Formação de professores para a docência online. Petrópolis: Edições Loyola, 2012. 
SILVA, Marco; CILENTO, Sheilane Avellar. Formação de professores para docência online: considerações sobre um estudo de caso. Revista da FAEEBA: Educação e

Contemporaneidade, v. 23, n. 42, p. 207-218, jul./dez. 2014. Disponível em:

http://dx.doi.org/10.21879/faeeba2358-0194.2014.v23.n42.p\%25p. Acesso em: 13 jun. 2018.

SILVA, Roberto Ribeiro da; MACHADO, Patrícia Fernandes Lootens; TUNES, Elizabeth. Experimentar Sem Medo de Errar. In: SANTOS, Wildson Luiz Pereira; MALDANER. Otavio Aloisio. (org). Ensino de Química em Foco. Ijuí-RS: Editora Unijuí, 2010. p.231-261.

TARDIF, Maurice. Saberes docentes e formação profissional. Petrópolis, RJ: Vozes, 2012.

VASCONCELOS, Carlos Alberto; VIEIRA, José Erisvaldo Lessa; DANTAS Isis Mota Rodrigues. Docê/ncia online e formação de professores: (re)significando os saberes docentes. In: Seminário Educação - SemiEdu, 2015: Educação e seus sentidos no mundo digital. Anais... Cuiabá: UFMT, p. 4192-4203, 2015.

Recebido em: 5 de maio de 2020.

Aprovado em: 15 de julho de 2020. 